Northern Review

yukoncollege.yk.ca/review

\title{
Gender, Critical Mass, and Natural Resource Co-Management in the Yukon
}

\author{
Kiri Staples and David Natcher
}

\begin{abstract}
Building on the research of White (2008) and Natcher (2013), who identified a paucity of female representation on co-management boards across the Canadian North, the research reported here set out to understand the implications of this gender imbalance for the experiences of women serving on natural resource co-management boards in the Yukon. Broadly speaking, resource co-management boards include a range of different institutional arrangements in which resource users and government come together to share management responsibilities (Yandle 2003). We explored whether critical mass-defined as a specific number or percentage of women necessary to make their participation within an institution effective-is considered by board members themselves to be a critical factor for the way women participate in co-management deliberations. Through semi-structured interviews with current and former board and staff members, our findings indicate that: 1) a majority of board members feel that the representation of women on co-management boards is necessary to the overall effectiveness of board decision making; and 2) women who served on boards with other female members experienced significantly fewer barriers to their participation than when they were the sole female representative. The intent of this article is to offer a practical application of critical mass theory and, more pragmatically, identify ways in which gender can be accounted for more effectively in co-management processes in Canada.
\end{abstract}

\section{Introduction}

Since the 1970s, the co-management of natural resources has become ubiquitous across the Canadian North. As noted by Natcher (2013), a conservative estimate counts more than forty different co-management boards that now share management and regulatory responsibilities for fish, water, wildlife, and other renewable resources, as well as land use 
planning. These management regimes have brought resource users together with various levels of Aboriginal and non-Aboriginal governments to engage in a more coordinated approach to natural resource management. While definitions abound, resource co-management has generally been defined as "a spectrum of institutional arrangements in which management responsibilities are shared between the users (who may or may not be community-based) and government" (Yandle 2003, 180). In the Canadian North, many of the existing co-management institutions that have emerged stem from the settlement of comprehensive land claims agreements, which among other outcomes have provided Aboriginal peoples with an influential role in the management of their traditional territories.

Resource co-management has received considerable scholarly attention, particularly in identifying the factors that either facilitate or impede effective collaboration, including power, culture, and epistemological diversity (e.g., Castro and Nielsen 2001; Nadasdy 2003a; Nadasdy 2003b; Natcher, Davis, and Hickey 2005; White 2008). Yet, largely absent from these critiques has been any consideration of gender, with only a few exceptions (Kafarowski 2005, 2009; Natcher 2013). In 2013, an inventory of board memberships conducted by Natcher found that the majority (176/210) of co-management board members in the three northern territories were male. This study, together with data published by White (2008), demonstrates that women have been significantly underrepresented on northern co-management boards. While accounting for the numerical representation of women on co-management boards serves as a necessary starting point, these numbers alone tell us little about what gender imbalance actually means, if anything, to participatory experiences of female board members.

With this article we hope to answer these questions and, by doing so, draw greater attention to the gendered dimensions of resource comanagement in Canada. This article focuses specifically on the experiences of co-management board members (past and present) in the Yukon. Among the three northern territories (Yukon, Northwest Territories, and Nunavut), the Yukon currently has the highest level of female representation (18\%) (Natcher 2013). We explore whether critical mass-defined as a specific number or percentage of women necessary to make their participation within an institution effective (Agarwal 2010b) - is considered by board members themselves to be a critical factor for participation and decision making within co-management boards. Approached in this way, our intent is to offer a practical application of critical mass theory and, more pragmatically, identify ways in which gender can be accounted for more effectively in comanagement processes in Canada. 


\section{Background}

An extensive body of research has demonstrated the importance of gender in the context of resource management institutions. Reed and Davidson (2011) propose that gender functions in conjunction with other social structures and processes to influence the type of knowledge, values, and concerns that are brought to the table in community-based natural resource management. These are based on the different roles, responsibilities, and experiences that men and women have within the community in relation to the natural environment (Mikkelsen 2005; Varghese and Reed 2012). For example, Reed and Varghese (2007) show that men are more likely to associate the environment with utilitarian values, whereas women convey stronger support for its intrinsic value. This does not imply that women's perspectives on the environment are homogenous; rather, that gender is one of many social structures that interact to influence the perspectives expressed within resource management.

In the context of resource management institutions that are based in or engage with communities, such as co-management boards, accounting for multiple interests is foundational to determining their effectiveness and institutional sustainability. These institutions require community members to both co-operate and act as a group in regard to a common-pool resource. ${ }^{1}$ Ensuring that a broad range of needs and values are included in their processes is central to that goal (Agarwal 2010a). However, the engagement of communities in natural resource management does not inherently address inequalities based on gender and other forms of social difference (Reed and Varghese 2007). More broadly, the gender composition of public bodies can influence how they function and the decisions they make. For example, research has linked the presence of women within government bodies to decreased corruption (Swamy et al. 2001), and their presence within natural resource management groups to improved collaboration, solidarity, and conflict resolution (Westermann, Ashby, and Pretty 2005).

A crucial component of the existing literature on gender representation and participation is the concept of critical mass. Much of the literature pertaining to critical mass can be found in business, education, and politics sources, with less application in environmental management research (Richardson et al. 2011). Regardless of the specific context, Kanter (1977) argued that anything below $15 \%$ female representation should be considered little more than tokenism, and a minimum of $30 \%$ female representation is needed for institutions to perform most effectively (Acharya 2006). While this specific percentage has been debated, the generally agreed upon threshold of women's representation for effective participation is 
around one-quarter to one-third (Richardson et al. 2011). In cases where this critical mass or threshold is not reached, women can, because of their minority representation, be subjected to marginalization and made to feel "invisible" in decision-making processes (Westermann et al. 2005). In cases where critical mass is reached or surpassed, more supportive institutional environments are created in which women can overcome potential reticence and speak out on issues and concerns in the presence of supportive female colleagues (Agarwal 2010, 99). Through the enhanced representation of women, it is argued, natural resource management is improved through collaboration, group solidarity, and a genuine willingness among members to resolve conflicts (Westermann et al. 2005, 1795). Broome (2011), however, urges some caution by suggesting that critical mass alone will not lead to greater equity, or more informed management outcomes, in cases where societal inequalities pervade. Rather, the numeric increases of traditionally underrepresented groups can result in heightened levels of discriminatory behaviour. Consequently, the relationship between critical mass and effective participation is far from a given. In light of the lack of research on the themes of gender and critical mass in the context of co-management in the Yukon, this research set out to explore their potential relevance to the perspectives and experiences of female board members in particular.

\section{Co-Management in the Yukon}

Our research focused on wildlife co-management boards established under Yukon's Umbrella Final Agreement (UFA), a land claims agreement that paved the way for negotiating individual Yukon First Nation Final Agreements. While similar boards and councils exist across the Canadian North, they have various roles, jurisdictions, and levels of influence. Many of these institutions, including those in the Yukon, play a strictly advisory role, which can nonetheless yield considerable political power (White 2008). Chapters 16 and 17 of the UFA established several co-management boards within the territory, including the Yukon Fish and Wildlife Management Board (YFWMB), the YFWMB's Salmon Sub-Committee, and ten Renewable Resources Councils (RRCs). Operating at the territorial level, the YFWMB is the "primary instrument of fish and wildlife management in the Yukon." It is an advisory body consisting of twelve members appointed by the Minister of the Environment-six of whom are nominated by the Council of Yukon First Nations and six by the Government of the Yukon. The Salmon SubCommittee is also an advisory body consisting of ten members, two of whom are appointed from within the YFWMB membership (one appointee of the Yukon First Nations and another of the Yukon Government). The remaining 
members of the sub-committee are representatives of the federal Minister of Fisheries and Oceans, the Yukon River drainage basin, the Alsek River drainage basin, and the Porcupine River drainage basin. The purpose of this board is to act as a forum for public involvement related to salmon stock and fisheries management (Yukon Salmon Sub-Committee 2014). On both the YFWMB and the Salmon Sub-Committee, appointments are made for five-year terms.

The YFWMB works closely with Renewable Resources Councils (RRC). RRCs are local management bodies established in areas where individual land claims agreements have been signed. RRCs serve as community comanagement boards designed to represent the collective interests of both First Nation and non-First Nation community members who reside within the respective traditional territory of the signatory First Nation and are responsible for dealing with fish, wildlife, habitat, and forestry matters specific to their traditional territory. RRCs are represented by six community members, three nominated by the First Nation and three by the Yukon Government (YG), with an internally appointed chair. For this research, the YFWMB, the Salmon Sub-Committee, and five RRCs (North Yukon, Mayo, Laberge, Dan Keyi, and Alsek RRCs) were included. In order to capture cross-territorial dimensions of co-management, the Porcupine Caribou Management Board (PCMB) was also included.This board was established under the Porcupine Caribou Management Agreement of 1985, and includes members from the Gwich'in Tribal Council, Na-cho Nyak Dun, Vuntut Gwitchin, Government of Yukon, Tr'ondëk Hwëch'in, Inuvialuit Game Council, Government of Northwest Territories, and Government of Canada (PCMB 2014).

This study looked at eight different co-management boards, with current female representation on individual boards ranging between $0 \%$ and $83 \%$. On average, women made up $28 \%$ of board members at the time of the study. However, these figures are only a snapshot of the current level of representation, and may not reflect the actual proportion of women on boards that was experienced by some of the past board and staff members interviewed (see table 1). 
Table 1. Current gender representation of boards included in project ${ }^{2}$

\begin{tabular}{lccc}
\hline Board name & \# of women & \# of men & $\begin{array}{c}\text { \# of interviewees } \\
\text { from each board }\end{array}$ \\
\hline YFWMB & $2(18 \%)$ & $9(82 \%)$ & 7 \\
PCMB & $2(22 \%)$ & $7(78 \%)$ & 4 \\
Salmon Sub-Committee & $3(30 \%)$ & $7(70 \%)$ & 3 \\
Alsek RRC & $2(33 \%)$ & $4(67 \%)$ & 5 \\
Dan Keyi RRC & $2(33 \%)$ & $4(67 \%)$ & 3 \\
Laberge RRC & $5(83 \%)$ & $1(17 \%)$ & 4 \\
Mayo RRC & $0(0 \%)$ & $5(100 \%)$ & 1 \\
North Yukon RRC & $1(14 \%)$ & $6(86 \%)$ & 4 \\
\hline
\end{tabular}

\section{Methods}

The primary method of data collection was semi-structured interviews that took place between May and September of 2013. Invitations to participate in this project were sent to all current co-management boards. In some cases, this was followed by a presentation to the board explaining the details of the research. Participants were then contacted individually. Past members were identified via publicly available documents and invited to participate where contact information was available. In some cases, interviews with female board members were sought out specifically. Given the research topic, it is possible that self-selection bias meant that those individuals who were interested in or aware of gender issues were more likely to participate in the interview. As a result, the data I interpret may not be representative of all perspectives on issues related to gender. This was mitigated to some extent by highlighting aspects of the project that were accessible to a wider audience, such as effectiveness and decision making. However, there was only so much that could be done to mitigate any assumptions associated with a project related to gender.

After piloting an interview guide with three current co-management board and staff members, twenty-nine semi-structured interviews were conducted in person $(n=24)$ and via telephone $(n=5)$. Interviews ranged from twenty minutes to over an hour, and questions related to participant experiences with gender, participation, and board decision making. Followup questions were sent by email, as required. Interview participants included individuals no longer involved in co-management $(n=9)$ as well as those who were still active on a co-management board at the time of the study $(n=20)$. Participants were either board members $(n=20)$ or staff members $(n=8)$, with 
one participant having experience in both positions. More women $(\mathrm{n}=21)$ participated in interviews compared to men $(n=8)$, and slightly more nonFirst Nations individuals $(\mathrm{n}=17)$ participated in comparison to First Nations individuals $(n=12)$. Each age category was represented, although the majority of participants fell into the 40-49 and 60+ age categories. Despite the small sample size, interview participants had together accumulated 112 years of service with co-management boards (fig. 1).

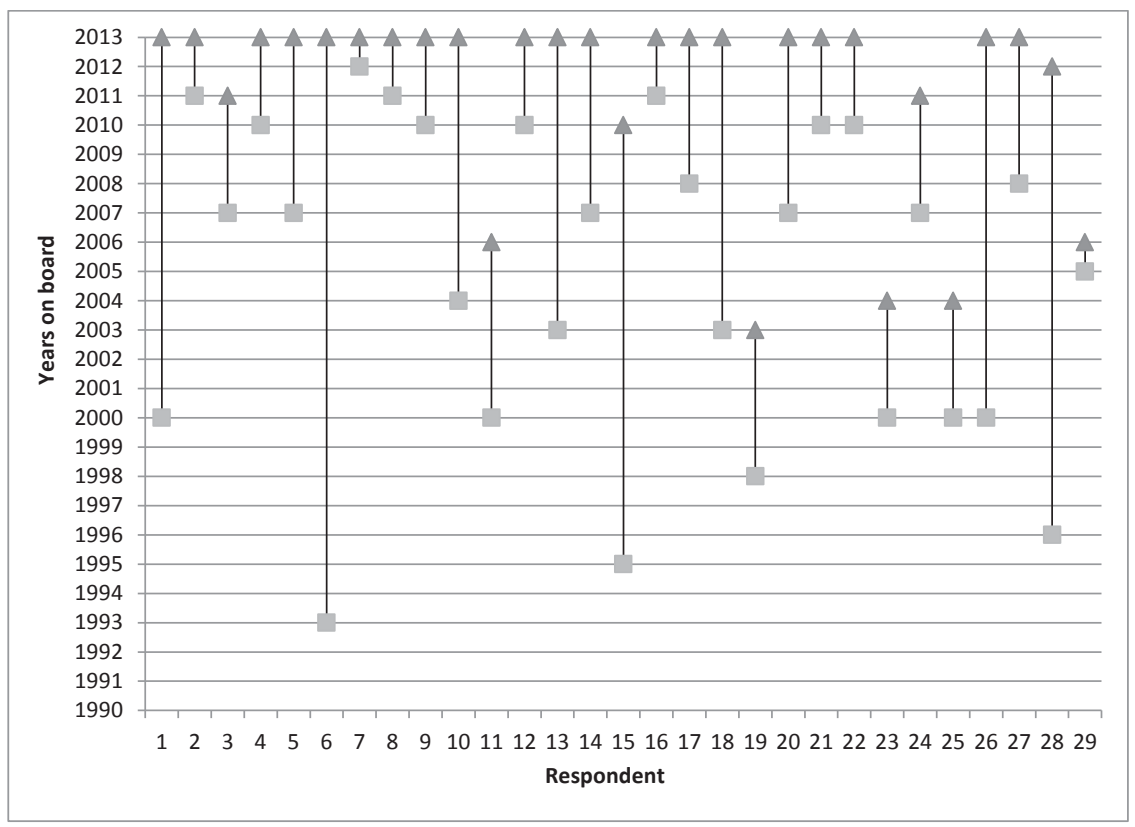

Figure 1. Number of years on board(s), by interview participant

Any identifying information associated with interview participants, such as name or co-management board that they were a member of, was kept confidential in all publicly available documents. All of the data was stored securely. Even with such measures in place, participants were also informed prior to the interview that in light of the relatively small number of people involved in co-management in the Yukon, complete anonymity could not be guaranteed. Consequently, participants reviewed the transcripts of their interview, and only the content that they were comfortable with was released. 


\section{Results}

It is important to note that a key finding of this work is that there is no single shared experience of co-management in the Yukon. Rather, there is a diverse range of experiences that vary between individuals and boards; in some ways these experiences overlap and in others they diverge. There are two major themes within these findings. The first relates to perceptions of women's representation on co-management boards. The second concerns the extent to which the concept of critical mass was reflected in the experiences of women on co-management boards. The majority $(90 \%)$ of interview participants thought it was important to have women represented on co-management boards, though often for different reasons (table 2). In general, reasoning fell into three broad categories: women's presence on co-management boards was important because board member diversity was important; women's representation positively influenced decision-making processes; and, most frequently, women brought a unique set of perspectives, knowledge, and experiences to the table. Four of the total participants $(n=29)$ in the interviews thought that women's representation on co-management boards was not relevant to the function of these boards. Three of these four individuals were female. They typically argued that gender had no impact on what they or other board members brought to the table.

Table 2. Reasons offered for why it is important to have women on co-management boards; summary of interview responses.

\begin{tabular}{lc}
\hline Reasoning $^{3}$ & $\begin{array}{c}\text { Percentage of total number } \\
\text { of references }(\mathbf{n}=60)^{4}\end{array}$ \\
\hline $\begin{array}{l}\text { Women bring unique perspectives, knowledge, and } \\
\text { experiences }\end{array}$ & $38 \%$ \\
$\begin{array}{l}\text { Women positively influence the decision-making } \\
\text { process }\end{array}$ & $22 \%$ \\
$\begin{array}{l}\text { Women's representation is important because board } \\
\text { member diversity is important }\end{array}$ & $12 \%$ \\
Women's representation does not matter & $6 \%$ \\
\hline
\end{tabular}

\section{Board Member Diversity}

The importance of having women on co-management boards was, for some participants, tied to ensuring diverse representatives on the board. For these respondents, gender was not necessarily the most important aspect of diversity. Other factors important to represent within co-management boards included professional background, ethnicity, education level, and personality. In addition, age stood out as an aspect of diversity that was 
important to many of the participants. The lack of youth involvement in co-management, exemplified by the minority of participants in the 20-29 age category, was of particular concern. The implications of failing to represent this diversity within the board were described by one participant: "I'm surrounded by men with grey hair. You know, like it's the same thing over and over and over again and it's just that then you create this sort of homogenous type of approach to things" (board member, personal interview, August 14, 2013).

\section{Perspectives, Knowledge, and Experiences}

The most common answer amongst participants discussing the importance of women's representation was a reference to the perspectives, knowledge, and experiences that women brought to the table. These contributions are in many ways shaped by the gendered roles found within different aspects of their lives, in particular women's roles in the community and on the land. However, these perspectives are engaged to different extents by comanagement boards.

Participants reflected the perception that women bring a communityminded perspective to co-management. This connection was central to representing broader grassroots-level interests. Yet, ensuring that these perspectives were a part of the discussions on co-management boards was not always a priority. As one female participant stated:

... it's so hard to break out of that paradigm. Like it's about this idea that when it comes to this decision making, providing advice, if it's about fish and wildlife then it's a man's thing. But it's so much more about community, right ... in a lot of cases that's what these boards and councils are supposed to be about. And so it's not necessarily that it's not supposed to be about fish and wildlife, but it's not just supposed to be about hunting, it's supposed to be about all of the interests. (Board member, personal interview, August 14, 2013)

While this connection to the community as a whole was associated exclusively with women, experience on the land was an important part of being a board member, regardless of gender. Having experience on the land was important for male and female, First Nation and non-First Nation participants alike. Those with knowledge of the land not only gained the respect of other board members, but also provided an important source of first-hand information for what is happening on the land. As one male participant described: "I think just being outside, being out there on the 
land, which I try to do as much as I can ... I mean I do that because I enjoy it. But in the same token, when you do that, it also builds some credibility for you" (personal interview, 10 June 2013).

Aboriginal land use has typically been organized by a gendered division of labour. Traditionally, First Nations men in the Yukon were seen as responsible for the hunting and harvesting of wildlife, while women processed meat and used hides to make clothing and supplies (Whitehorse Aboriginal Women's Circle, 2010). These roles were both complementary and flexible. Participants reported that these gendered roles still exist today, but have never been entrenched or static. Rather, four (19\%) of the women that were interviewed self-identified as hunters. The land-based activities that women mentioned most often included berry picking, taking youth on the land, fishing and the running of fish camps, canoeing, and gathering traditional medicines, to name a few. Yet, similar to women's roles within the community, engaging women's knowledge of the land was not always a priority for co-management boards (Staples and Natcher, 2015). One male participant explained: "activities that women undertake like 'gathering' type activities are considered very occasionally, but not like 'hunting/ fishing/trapping' activities. Gathering is a fascinating consideration in the grand scheme because it is traditional, important, and particularly because products being 'gathered' are sessile; activities such as exploration, mining, roads, and even tourism can have significant effects on them" (pers. com., October 21, 2013).

\section{Critical Mass}

Female interviewees provided a mix of responses in reflecting on the concept of critical mass within their own experiences. While some generalizations can be made, there are exceptions to each trend. Nonetheless, this range of experiences provides insight into the relationship between women's representation and their effective participation within co-management. Women's perceptions of critical mass typically fell into two categories of experiences. The first group included female participants with experiences on co-management boards where the number of female representatives was consistent throughout their involvement. The actual number of women on these boards varied from participants being the only woman on a board to having one or more other female board members. However, the one factor they had in common was that this number had not changed. Although these participants acknowledged that there may be some differences in how they related to female board members compared to their male counterparts, they found that the number of women on their board had no influence on 
their participation in board decision making. Moreover, they did not think that having a greater or fewer number of women on the board would have influenced this experience. In cases where women made up the majority of board members, female board members not only thought that the concept of critical mass had no application to their situation, but also perceived gender as having no influence on board decision making in general.

The second group was made up of those who had been on one or several boards with various levels of female representation. These women had, at different points in time, been the only woman on a board, as well as on a board with one or more other women. In contrast to the previous category of participants, the experiences of these board members demonstrated more support for the concept of critical mass. These women reflected that the barriers towards being able to participate effectively were greater in cases where they were the only woman on the board. In comparison, they found that having another female board member in the room meant they were more likely to have their voices heard. One female board member compared her experiences coming onto a board with a female chair versus one where she was the only woman. She explained that with a female chair already in place, "that authority has already been exercised there, but if you're coming into an all-men committee, yeah it is different. Big difference. You have to prove yourself. Prove your knowledge" (female board member, personal interview, July 4, 2013). This quote in particular draws attention to the fact that critical mass is not a static concept. While the actual number of women on a board may vary, the concept of having to "prove" yourself implies that once this has been done, your knowledge will be valued regardless of numerical representation.

Having to "prove" yourself on a board made up predominantly of male board members was discussed by five out of twenty-one female interviewees (24\%). Four of these five women also identified as First Nations. These women almost all fell into this second category of support for critical mass. However, these experiences did not reveal a specific number of women that created the conditions in which female board members felt their voices were being heard without having to prove themselves. Nonetheless, where women were able to compare experiences with different levels of female representation on one or more boards, they supported the general concept of critical mass leading to more effective participation. In other words, nominal representation, or having a "place at the table," did not necessitate effective participation, or having a "voice at the table" (Varghese and Reed 2012). 


\section{Discussion}

The findings of this research offer insight into a previously unexplored area of natural resource co-management in the Yukon. Participants in this study reflected the perception that a diverse board membership, including gender diversity, was important for ensuring that different perspectives and opinions were represented in their discussions and decisions. Similarly, a cross-country analysis by Das and Dirienzo (2010) demonstrated the importance of diversity to institutional efficacy. Many participants in our study expressed concerns over the challenges boards face in finding new members to achieve this diversity, particularly with regard to age and gender. The fact that those involved in co-management identify the importance of board member diversity, yet in many cases struggle to achieve it, underscores the significance of addressing these challenges. In fact, those involved on co-management boards found that the representation of women is relevant to their work in a number of ways. Nonetheless, women did not feel this recognition created an environment where their perspectives, knowledge, and experiences were equally appreciated or respected. Simply acknowledging that the representation of women is important to comanagement boards does not ensure the effective participation of women.

One question that emerges from this discussion is whether or not the experiences of female board and staff members would have been different if there were more women involved in co-management institutions. In other words, does the concept of critical mass apply to co-management boards in the territory? Of the eight co-management boards included in this project, four were below the often-quoted one-quarter to one-third representation threshold. Three fell within the one-third percentage threshold, and one was significantly above it. While these percentages are in some ways misleading, as the total number of board members on some boards is very low, they do demonstrate the diversity of experiences captured within the results of this work. Accordingly, the perceptions of interview participants in regard to critical mass were similarly diverse. Nonetheless, there was support for this concept where women on co-management boards had a range of experiences with different levels of female representation. This does not imply that all women who worked on boards where they were the only woman felt marginalized. However, it does indicate that for many women, having greater female representation on a co-management board improved their ability to participate effectively. Moreover, in light of the fact that four out of five of the women who discussed having to "prove" themselves identified as First Nations, gender is not the only factor that influences the ability to have one's voice heard. These findings are significant in that they demonstrate 
the importance of looking beyond nominal representation when discussing gender and other social structures within natural resource management institutions. While similar arguments have been made elsewhere (e.g., Arora-Jonsson 2008; Reed and Davidson 2011), relatively little has been done to explore these themes in a northern setting. Based on the experiences discussed here, this is a worthwhile avenue of analysis to pursue, specifically as it relates to decision making (see Staples and Natcher, 2015).

It is important to note that simply appointing more women to comanagement boards is not necessarily going to address the issues of effective participation that have been identified here. This is not to say that having more women on co-management boards is not a worthwhile goal. Indeed, at the Yukon Aboriginal Women's Summit, one of the key priorities was to "increase representation of Aboriginal women at decision-making tables dealing with water, land, and traditional knowledge" (Women's Directorate and Yukon Advisory Council on Women's Issues 2007). Moreover, given the findings here (and elsewhere) on critical mass, there is evidence to support the value of this goal. However, several of the major government bodies responsible for appointing or nominating co-management board members already take into account the concept of gender equality, on paper at least. The Council of Yukon First Nations (CYFN) Board Selection Committee, for example, lists "gender equity" first on its list of criteria for consideration (Council of Yukon First Nations 2007). Though there is not a specific number or percentage associated with this criterion, the committee is generally aware of gender equality in relation to the number of total seats on the board (discussion with CYFN employee, Whitehorse, Yukon, June 20, 2013). Similarly, the Yukon Government's policy on boards and committees includes the following section:

1.3.1 In cases where the Yukon Government is the sole appointing authority, and where membership is not already defined by legislation, the Yukon Government is committed to membership on government boards and committees that is representative of Yukon society, including gender, age, First Nations people, youth, visible minorities and people with disabilities. In other instances, the Yukon Government will make best efforts to ensure that nominations and appointments of members to boards and committees ensure representation of gender, age, First Nations people, youth, visible minorities and people with disabilities. (pers. com. with Yukon Government employee, Whitehorse, Yukon, June $25,2013)$ 
While it is encouraging that these government bodies are aware of gender when selecting candidates, this attitude can easily be co-opted into treating women as tokens of equality rather than valuing them for their contributions to co-management institutions. For this reason, it is important to ensure that opportunities for filling board member positions are structured to be more inclusive to women, so that women both want and are able to participate.

\section{Conclusion}

In light of the current gaps in research on gender and natural resource management in the Canadian North, this research aimed to explore the relationship between gender representation and participation on comanagement boards in the Yukon. Building on work by White (2008) and Natcher (2013) that identified a paucity of female representation on comanagement boards across the North, this research set out to understand what the implications of this imbalance are in regard to the perceptions and experiences of those involved in co-management. Participants found that the representation of women on co-management boards is relevant to improving board member diversity and influencing the process of decision making.

Participants also acknowledged the importance of the knowledge, perspectives, and experiences that women bring to the table, based on gendered roles in the community and on the land. Despite the fact that participants almost unanimously agreed that the representation of women on co-management boards was important, this did not always translate into the effective participation of female board and staff members. Women who were able to compare the experience of being the only woman on a board with the experience of having other women on a board with them found that the latter situation presented fewer barriers to their participation. This support for the concept of critical mass in a natural resource management setting has also been found within the Canadian forestry sector (Richardson et al. 2011). Similar studies have yet to emerge in the other two northern territories, despite the fact that the proportion of women on co-management boards in the Northwest Territories and Nunavut is lower than that of the Yukon (Natcher 2013). For some, the transition to acknowledging the importance of gender in a resource management setting is already underway, albeit slowly. As one woman stated: "it has changed a little bit but not so much so that I would say that we're ... on equal grounds" (board member, personal interview, July 4, 2013). 


\section{Acknowledgements}

This research was made possible through the support of the Social Sciences and Humanities Research Council (SSHRC), Resources and Sustainable Development in the Arctic (ReSDA), University of Saskatchewan, Association of Canadian Universities for Northern Studies (ACUNS), Northern Scientific Training Program, and Yukon Research Centre.

\section{Authors}

Kiri Staples is a recent MES graduate from the School of Environment and Sustainability, University of Saskatchewan.

David Natcher is professor, Department of Bioresource Policy, Business and Economics at the University of Saskatchewan, and Director of the Indigenous Land Managment Institute.

\section{Notes}

1. Common pool resources are subtractable (part of the resource used by one person cannot be used by another) and excludable (difficult to exclude others from) (Acheson 2006).

2. These numbers only capture the current representation of men and women on co-management boards; it is likely that, in some cases, this number would not be accurate for the past board and staff members who were interviewed. Because a number of interviewees had experiences on more than one board, the total number of interviewees presented here is not representative of the total number of individuals interviewed.

3. The remaining responses fell into a broad "other" category that had no unifying theme.

4. Sixty references, within twenty-nine interviews, were made to the factors that contributed to a good decision. Several participants referred to more than one factor.

\section{References}

Acharya, K.P. 2006. Improving the Effectiveness of Collective Action: Sharing Experiences from Community Forestry in Nepal. CAPRi Working Paper 54. Washington D.C.: International Food Policy Research Institute.

Acheson, James M. 2006. Institutional Failure in Resource Management. Annual Review of Anthropology 35 (1) (October): 117-134. doi:10.1146/annurev. anthro.35.081705.123238.

Agarwal, Bina. 2010a. Gender and Green Governance: The Political Economy of Women's Presence Within and Beyond Community Forestry. Vol. 9780199569. Oxford/New York: Oxford University Press. 
- 2010b. Does Women's Proportional Strength Affect Their Participation? Governing Local Forests in South Asia. World Development 38 (1) (January): 98-112. doi:10.1016/j.worlddev.2009.04.001.

Arora-Jonsson, Seema. 2008. A Different Vantage Point: Decentralization, Women's Organizing and Local Forest Management. In Lessons from Forest Decentralization: Money, Justice and the Quest for Good Governance in Asia-Pacific, edited by C.J. Pierce Colfer, G.R. Dahal, and D. Capistrano, 49-64. London: Earthscan.

Broome, Lissa Lamkin, John M. Conley, and Kimberly D. Krawiec. 2011. Does Critical Mass Matter? Views From the Boardroom. Seattle University Law Review 34: 1048-1080.

Castro, Alfonso Peter, and Erik Nielsen. 2001. Indigenous People and Co-Management: Implications for Conflict Management. Environmental Science \& Policy 4 (4-5): 229-239. doi:10.1016/S1462-9011(01)00022-3

Council of Yukon First Nations. 2007. Boards Selection Committee: Criteria \& Considerations of Selection. Whitehorse, YT: Council of Yukon First Nations. http://webgui.cyfn.ca/ uploads/jH/AT/jHATUakImtirfH12O4fBpw/CYFN-Boards-Criteria.pdf.

Das, Jayoti, and Cassandra E. Dirienzo. 2010. Is Ethnic Diversity Good for the Environment? A Cross-Country Analysis. The Journal of Environmental Development 19 (1): 91-113. doi:10.1177/107049650355274

Kafarowski, Joanna. 2005. "Everyone Should Have a Voice, Everyone's Equal": Gender, Decision-Making and Environmental Policy in the Canadian Arctic. Canadian Woman Studies 24 (4): 12-17.

Kanter, R.M. 1977. Some Effects of Proportions on Group Life: Skewed Sex Ratios and Responses to Token Women. The American Journal of Sociology 82(5): 96-990.

Mikkelsen, Caecilie. 2005. Indigenous Peoples, Gender, and Natural Resource Management. 2005/5. Copenhagen. http://subweb.diis.dk/graphics/Publications/ WP2005/cmi_indigenous_peoples.pdf.

- ed. 2009. Gender, Culture, and Northern Fisheries. Edmonton: Canadian Circumpolar Institute Press.

Nadasdy, Paul. 2003a. Reevaluating the Co-Management Success Story. Arctic 56 (4): 367-380.

-2003b. Hunters and Bureaucrats: Power, Knowledge, and Aboriginal-State Relations in the Southwest Yukon. Vancouver, BC: University of British Columbia Press.

Natcher, David. 2013. Gender and Resource Co-Management in Northern Canada. Arctic 66 (2): 218-221.

Natcher, David, Susan Davis, and Clifford G. Hickey. 2005. Co-Management: Managing Relationships, Not Resources. Human Organization 64 (3): 240-250.

Porcupine Caribou Management Board. 2014. "About the PCMB.” http://www.taiga. net/pcmb/pcmb.html.

Reed, Maureen, and Debra Davidson. 2011. Terms of Engagement: The Intersections Among Gender, Class and Race in Canadian Sustainable Forest Management. 
In Reshaping Gender and Class in Rural Spaces, edited by Barbara Pini and Belinda Leach, 199-230. Burlington, VT: Ashgate Publishing Company.

Reed, Maureen, and Jeji Varghese. 2007. Gender Representation on Canadian Forest Sector Advisory Committees. The Forestry Chronicle 28 (4): 515-525.

Richardson, Kristyn, A. John Sinclair, Maureen Reed, and John R. Parkins. 2011. Constraints to Participation in Canadian Forestry Advisory Committees: A Gendered Perspective. Canadian Journal of Forest Research 41 (3): 524-532. doi:10.1139/X10-220.

Staples, Kiri, and David Natcher. 2015. "Gender, Decision-making, and Natural Resource Co-management in Yukon." Arctic 68 (3): 356-366. doi:10.14430/ arctic4506

Swamy, Anand, Stephen Knack, Young Lee, and Omar Azfar. 2001. Gender and Corruption. Journal of Development Economics 64 (1): 25-55. doi:10.1016/ S0304-3878(00)00123-1

Varghese, Jeji, and Maureen Reed. 2012. “Theorizing the Implications of Gender Order for Sustainable Forest Management." International Journal of Forestry Research 2012: 1-11. doi:10.1155/2012/257280

Westermann, Olaf, Jacqueline Ashby, and Jules Pretty. 2005. Gender and Social Capital: The Importance of Gender Differences for the Maturity and Effectiveness of Natural Resource Management Groups. World Development 33 (11): 1783-1799. doi:10.1016/j.worlddev.2005.04.018

White, Graham. 2008. "'Not the Almighty': Evaluating Aboriginal Influence in Northern Land-Claim Boards.' Arctic 61 (1): 71-85.

Whitehorse Aboriginal Women's Circle. 2010. “Traditional Roles of Yukon First Nations Women." http://www.wawc.ca/index.php?option=com_content\&view $=$ article $\&$ id $=93 \&$ Itemid $=242$.

Women's Directorate, and Yukon Advisory Council on Women's Issues. 2007. Strong Women, Strong Communities: Furthering Aboriginal Women's Equality - Priorities and Key Messages. Whitehorse, YT. http://www.womensdirectorate. gov.yk.ca/pdf/yaws2.pdf.

Yandle, Tracy. 2003. 'The Challenge of Building Successful Stakeholder Organizations: New Zealand's Experience in Developing a Fisheries Co-Management Regime.' Marine Policy 27 (2): 179-192. doi:10.1016/S0308-597X(02)00071-4

Yoder, Janice D. 1991. Rethinking Tokenism: Looking Beyond Number. Gender and Society 5: 178-192.

Yukon Bureau of Statistics. 2006. Census 2006: Aboriginal Data. Whitehorse, YT. http://www.eco.gov.yk.ca/pdf/aboriginadata.pdf.

—. 2013. Population Report: September 2013. Whitehorse, YT. http://www.eco. gov.yk.ca/stats/pdf/populationSep_2013.pdf.

Yukon Salmon Sub-Committee. 2014. "Mission, Powers \& Authorities." http://yssc. ca/about/mission. 